\title{
Arab Spring and the Jordanian Muslim Brotherhood Organization
}

\author{
Nigar Nese Kemiksiz \\ Anka Institute, Ankara, Turkey \\ Email:n.kemiksiz@ankaenstitusu.com
}

How to cite this paper: Kemiksiz, N. N. (2022). Arab Spring and the Jordanian Muslim Brotherhood Organization. Open Journal of Political Science, 12, 144-161. https://doi.org/10.4236/ojps.2022.122009

Received: December 22, 2021

Accepted: February 19, 2022

Published: February 22, 2022

Copyright $\odot 2022$ by author(s) and Scientific Research Publishing Inc. This work is licensed under the Creative Commons Attribution International License (CC BY 4.0).

http://creativecommons.org/licenses/by/4.0/

\begin{abstract}
This article deals with the relations between the Jordanian Muslim Brotherhood Organization $(\mathrm{MBO})$ and the Jordanian regime during and after the Arab Spring and aims to reveal how the Arab Spring affected the relations. That the MBO, performing legal activities in Jordan since 1945, was terminated upon the judicial decision in July 2020 constituted great importance due to eliminating the activities of the most powerful opposing organization in the country. The Arab Spring became a milestone in the relations between the Jordanian MBO and the Hashemite Monarchy. It is thought that the Jordanian MBO expected to form a Muslim Brotherhood line in the region exhibited a competitive attitude against the regime and aimed to weaken the legitimacy of the regime. However, the fact that the Arab Spring was not progressed in an expected way, particularly the fact the Egyptian MBO was overthrown by the military coup, constituted a significant impact on the Jordanian MBO, as it did to all Muslim Brotherhood Organizations. After the military coup, the renewed regional balance provided the proper conditions, so that the Jordanian regime was able to marginalize the $\mathrm{MBO}$. Within this scope, the Jordanian regime adopted an action that was executed over time and the radical wing of the organization, regarded as a supporter of Hamas, was disbanded. The article concludes that the Arab Spring consolidated the concept of strengthening the Jordanian identity of the state and ensured the Jordanianization of the MBO just like in the other critical processes in the recent past of Jordan.
\end{abstract}

\section{Keywords}

Jordan, Muslim Brotherhood Organization, Hashemite Monarchy, Arab Spring, Hamas

\section{Introduction}

Jordanian MBO, unlike Muslim Brotherhood organizations in most Arab coun- 
tries, had opportunity to operate legally in Jordan for many years and maintained positive relations with the regime. To share the same opinions on significant issues with Hashemite Monarchy and have common enemies led Jordan $\mathrm{MBO}$ to support the regime for many critical issues. Within this framework, Jordan MBO had supported King Abdullah I's decision to annex West Bank in 1950 and had taken side with the regime against Arab nationalism and leftist movements which influenced the Middle East under the charismatic leadership of the Egyptian leader Nasser between 1950s and 1960s and threatened the Jordan monarchy. Not being involved in the 1970-1971 civil wars between Palestinian organizations and Jordan Army enabled MBO to be efficient in Palestine refugee camps and to strengthen its social grassroots. Due to being the only organization operating legally after 1957 when the political parties were banned, MBO achieved a historical success in 1989 elections.

The Middle East peace process which began in the early 1990s led the relations between Jordan $\mathrm{MBO}$ and the regime to be changed and $\mathrm{MBO}$ to stand by the opposition. The signing of the Jordan-Israeli peace treaty in 1994 directed MBO to cooperate with other opposition organizations in demonstrations intending to prevent normalization with Israel. On the other hand, MBO didn't go beyond the political reform demands and didn't set out an anti-regime stance.

The accession of King Abdullah II in 1999 and the changing international and regional conditions since the 2000s led to the development of a security-oriented approach to the MBO. Second Palestinian Uprising (Intifada) starting in 2000, USA's adoption of the global fight against terrorism strategy after 11 September 2001, and Iraq's occupation in 2003 caused a period of terrorism, sectarian conflicts, and instability in the Middle East. In 2005, the Hashemite Monarchy was exposed to the most violent terrorist attacks in its history. In 2006, Hamas' victory in the Palestinian Legislative Council elections was an effective factor in hardening the regime's stance against MBO. From this period, it is observed that the regime has enhanced its control over $\mathrm{MBO}$ and has determined to reduce its representation and political role in the parliament and to constrict its relations with Hamas. Before the 1970-71 civil wars, Palestine Liberation Organization (PLO) efficient works on Palestinian refugees who are citizens of Jordan caused the regime to follow a careful stance for Palestinian Organizations and Palestinian-origin Jordanians. For this reason, Hamas's efforts for controlling Jordan $\mathrm{MBO}$ and the presence of Palestinian-origin Jordanians close to Hamas under the leadership of $\mathrm{MBO}$ are the issues that the regime is uncomfortable with.

Arab Spring protests in Jordan generally took place peacefully, the demands for overthrowing the regime were not mentioned as in the demonstrations in other Arab countries, and the Jordan MBO didn't go beyond the reform demands But, the connections with Egypt $\mathrm{MBO}$ and the perception that it avoided cooperation with the regime by the recommendations of MBO Guidance Office caused the regime to doubt the real intentions of Jordan MBO. Arab Spring followed a different direction due to involvement of terrorist organizations, mili- 
tary coup ending MBO government in Egypt, western countries' focuses on counter terrorism instead of regime changes and region countries' attempt to ban $\mathrm{MBO}$ or to declare it as a terrorist organization has also affected Jordan MBO's position. At the end of 2012, disagreements in the MBO concerning organization's course of action gained a serious dimension with mutual critics and accusations and resulted in expelling some of the MBO leaders. The expelled leaders have established and registered a new organization named Muslim Brotherhood Association (MBA) in 2015 in order to protect Jordan MBO from the same end as Egypt MBO. Thus, MBO's legal status has become controversial. The lawsuit which was filed by MBO in July 2020 at the discretion of transferring its assets to the new association has been concluded by adjudging the abolishment of the organization and ending the legal presence of MBO.

In this article, it is aimed to analyze the factors that were effective in the ending of relations which had followed a negative course since the early 2000s within the framework of Arab Spring and the possible consequences of abolishment decision. The importance of the Jordan MBO in Jordan's social and political life, its relations with Hamas and its impact on Jordanians of Palestinian-origin constitute the rationale for this study. The article which has been carried through a literature review involves the development of regime-MBO relations since 1945 . In the first part of the study, which consists of two parts, the situation of the relations between the Jordan MBO and the regime before the Arab Spring is discussed, and in the second part, the effects of the Arab Spring and the developments after it on the relations are emphasized.

\section{Relations before Arab Spring}

The relations between Jordan $\mathrm{MBO}$ and regime before Arab Spring can be studied in two periods. These periods have different meanings and characteristics in terms of the relations. The period between 1945 and 1999, was a period in which the relations followed a positive course at least until 1993 and the notion of cooperation was dominant. The relations which started to deteriorate with the signing of the Israel-Jordan peace agreement in 1994 had been radically changed after Abdullah II succeeded to the throne in 1999.

\subsection{5-1999 Period}

Since 1945, MBO, as a Jordanian branch of Egypt MBO, has established positive relations with the regime in Jordan where it was operating firstly as a charity organization and then as an Islamic community status. The belief in the importance of friendly relations with a Muslim organization in order to strengthen the authority and legitimacy of King Abdullah I, who came from the Hejaz and did not have any local ties to Transjordan, was effective in the positive course of relations (Wagemakers, 2020). In the beginning, MBO was mostly interested in religious education and charities; after the 1948 Arab-Israel War, it took a more active approach to gain influence among Palestinian refugees who had come into 
the region and started to compete with secular organizations (Wagemakers, 2020). Jordan MBO had supported Abdullah I's the annexation of the West Bank to Jordan decision in 1950 and it interpreted this decision as the establishment of Jordan-Palestine Muslim union/brotherhood.

MBO's positive relations with the regime continued after King Hussein succeeded to the throne in 1953. During years 1950s and 1960s, MBO cooperated with the regime against the Arab nationalists and leftist groups threatening the monarch and took its place next to Hussein during the coup attempts of Nasserites against King Hussein. In return for this cooperation, $\mathrm{MBO}$ was allowed to continue its activities while all political parties in the country were banned in 1957. The fact that MBO wasn't involved in 1970-1971 Jordan civil wars between Palestinian groups and Jordan army led MBO to be allowed to fill the power vacuum in the Palestinian refugee camps after PLO was driven out of Jordan (Abu Rumman, 2007). This development enabled MBO to gain strength among Palestinian-origin Jordanians and to extend its social base. On the other hand, the fact that the only option for Palestinians who want to engage in opposition politics after the civil war is to bring their religious identities to the fore, not their ethnicity, has increased the importance of the MBO (Turan, 2011). The Jordan $\mathrm{MBO}$ has never been far from the developments in Palestine, mainly because the Jordan MBO General Comptroller is seen as the official leader of Palestine MBO and both two organizations has established together Great Syria MBO which included Gaza, West Bank and Jordan in 1978 (Abu Rumman \& Abu Haniyeh, 2013). For this reason, the decision of King Hussein to cut administrative and legal ties with the West Bank in 1988 was criticized by the MBO. After the First Palestinian Intifada which had been started in 1987, Israel's "Jordan is Palestine" discourse had been seen as a threat to Jordan's security and it is aimed to reduce the threats from both Israel and Palestine by proving the difference between Jordan and Palestine with the decision of leaving West Bank (Lucas, 2005). After the decision of West Bank, Jordan's identity had been radically changed and the "Jordan is Jordan, Palestine is Palestine" approach was accepted (Lynch, 2002).

In 1989, Jordan Government started a political reform process because of the uprisings in southern regions, preliminary in Maan where the tribes which constituted main support base for the regime were powerful. This pointed out a new era for $\mathrm{MBO}$. As it was the only organization that could operate legally after 1957, MBO had the opportunity to join Jordan's political life as the most powerful and organized group in 1989 when the parliament had been reopened. Gaining 34 chairs with other Islamic and independent candidates in the 80-member parliament has been a historic success for MBO.

After 1989, carrying out political activities in a semi-authoritarian political environment which was determined with the mixture of democracy and authoritarianism brought $\mathrm{MBO}$ into internal tension, separation and disagreement (Abu Haniyeh, 2016). Although the separations in MBO existed before, they were at a theoretical level but as the parliamentary life started in 1989 and some 
elections had to be realized, these separations became concrete (Wagemakers, 2020). The main separation in MBO is between hardliners (hawks) and moderates (pigeons). Hardliners are the more internationalist group that supports solidarity with Palestine and the MBO's relations with Hamas, while the pigeons are the more moderate, more Jordanian-oriented, and more cautious group about relations with Hamas. The issues related to Jordan's identity complicate this separation. Many Palestinian-origin Jordanians are identified with the hawks while Eastern Banker Islamists consider themselves as moderates (Ryan, 2015).

Losing the political and financial support of the USA and the Gulf countries due to its pro-Iraq stance during the 1991 Gulf War and facing economic difficulties due to the Gulf countries sending back hundreds of thousands of Palestinian-origin Jordanians, Jordan saw attending the Middle East Peace Conference, which was initiated at the end of 1991 with the initiative of the USA as an opportunity. On the other hand, the opposition groups, mainly $\mathrm{MBO}$, objected to coming to the table with Israel and the possibility of peace. The Jordanian government attempted to create a parliamentary arithmetic that would enable the ratification of the Jordanian-Israeli peace agreement, if signed, and enacted a new electoral law in 1993. The law, based on "one-person, one-vote" system aimed to strengthen representation of tribes that formed the base of the regime while reducing the representation of political parties. Within this framework, the representation of big cities with a high population of Palestinian-origin which constitutes the majority of $\mathrm{MBO}$ voters had been significantly reduced compared to rural regions with a predominance of tribes. The results of the 1993 elections demonstrated that the purposes of the government had been realized. MBO gained 17 chairs in the parliament where the chair number increased to 104. The restrictive characteristic of the electoral law had been a matter of debate for many years and its amendment had been one of the main reform demands of MBO. Although the opposition could not prevent the ratification of the Jordan-Israel peace agreement signed in 1994 in the parliament, it tried to prevent the normalization of relations with Israel, and the Anti-Normalization Committee, which was formed with the participation of various opposition groups, especially the $\mathrm{MBO}$, managed to form a perception against normalization in the public opinion with demonstrations and activities.

The signing of the peace agreement with Israel had been a turning point for relations between the Jordan regime and MBO and MBO's "loyal opposition" role came to an end. Although it boycotted the 1997 elections due to the rejection of their demand for electoral law amendment, MBO didn't put an anti-regime stance.

One of the significant developments of this period is the settlement of Hamas leaders who were expelled from Kuwait in Jordan in 1991. This development generated important results in terms of relations between Jordan regime and Hamas, Hamas and MBO, MBO and regime and separations in MBO. By allow- 
ing Hamas leaders activities in Jordan, King Hussein aimed to use Hamas as a trump card against the possibility of PLO leader Yasser Arafat, with whom he had a long struggle over the representation of the Palestinians, to make peace with Israel against the interests of Jordan. Jordan is an important country for Hamas leaders due to its proximity to the occupied territories, the presence of a large Palestinian population and the influence of Jordan MBO on Palestinian-origin Jordanians. However, although Hamas committed not to operate against Jordan's interest, its weapon storage in Jordan, its staff recruitment from Jordan MBO, its intervention to MBO's internal affairs and administrative staff caused to regime's reaction (Abu Rumman \& Abu Haniyeh, 2013). On the other hand, Hamas' stance increased separations in $\mathrm{MBO}$ and generated differences of opinions between hardliners and moderates. Although he signed the peace agreement with Israel in 1994, King Hussein allowed Hamas' Political Bureau activities and this situation lasted until he died in 1999.

\subsection{9-2011 Period}

The death of King Hussein in 1999, Abdullah II's succession to the throne and the developments that occurred in international and regional areas caused radical changes in the relations between the regime and MBO. Abdullah II closed the Hamas Political Bureau down in Amman at the end of 1999, expelled the Hamas leaders from Jordan, and showed his support for an independent Palestinian state. The decision on Hamas was important within the framework of the Jordanianization of $\mathrm{MBO}$ and strengthening Jordanian identity of the state (Lynch, 2002). King Abdullah II aimed to strengthen national integrity and to reform Jordan's identity by starting "Jordan First" campaign after the Second Intifada (Köprülü, 2015). Abdullah II who eliminated the criticisms of the Palestinian Authority by ending the activities of Hamas also adopted a different approach from his father regarding the relations with $\mathrm{MBO}$ and transferred the $\mathrm{MBO}$ file which was followed-up by the king himself as a political file to the security services (Abu Rumman, 2020). Abdullah's security-oriented approach was influenced by the stances of countries such as Saudi Arabia and Israel which consider Jordan $\mathrm{MBO}$ as an extension of Hamas and a part of the Islamic terrorism axis and groups who see $\mathrm{MBO}$ as a threat that must be eliminated within the regime (Milton-Edwards, 2015). From this period, the regime pursued a strategy against $\mathrm{MBO}$ which can be summarized as trying to ensure that it does not get enough votes to effect parliamentary decisions and to prevent their capacities in the institutions and networks in public arena that provide influence to $\mathrm{MBO}$ within the society (Abu Rumman, 2020).

The outburst of the Second Intifada in 2000, the USA's adoption of global fight approach against terrorism after the Al-Qaida attacks on 11 September 2001, the USA's Iraq invasion in 2003 and bringing the necessity of reform to the agenda with the idea that authoritarian and oppressive governments in the Middle East strengthen radicalism caused developments in the region, the effects of 
which will continue for a long time. Jordan Government who postponed the elections and suspended parliamentary activities decided to hold elections in 2003 and encouraged MBO's political branch Islamic Action Front (IAF) for participating in the elections. As the strongest and most organized opposition organization, the participation of the IAF in the elections was seen as a factor that would strengthen the democratic image of the regime. The chaos which emerged from resistance movements after the invasion of Iraq, sectarian conflicts and spreading terrorism showed its effect in Jordan in 2005 with the attacks of Iraq Al-Qaida to three hotels in Amman in which 60 persons dead. This development, which revealed the action capacity of the Salafi jihadists, has strengthened Jordan's security-oriented approach. In 2006, some IAF deputies including the Deputy Secretary General visited the family of Iraqi Al-Qaida leader Abu Musab Zarqawi for expressing their condolences. This led to the harsh reaction of the government and two deputies were sentenced to prison.

In this period, the development which worried Jordan mostly was that Hamas won the majority in the Palestinian Legislative Council elections in 2006. Hashemite Monarchy, which is uncomfortable with the fact that Jordan being seen as an alternative Palestinian homeland due to giving citizenship to Palestinian refugees unlike other Arab countries and the majority of its population consisting of Palestinian origins, sees the projects of the Palestinian organizations aiming to establish a Palestinian state in Jordan by overthrowing the monarchy as was in 1970-1971. For this reason, the Jordan regime was concerned about Hamas winning the Palestinian elections and worried that if Jordan MBO achieved the same success in Jordan, Hamas and Jordan MBO's desires of implementing Jordan-Palestine Muslim union would become stronger. Such a union which wouldn't be different from the "Jordan is Palestine" approach will obviously threaten the future of the Hashemite Monarchy. Within this framework, the Jordan regime aimed to constrict social and political role of Jordan $\mathrm{MBO}$, seized MBO's Islamic Charity Center Association in 2006 on the grounds of financial and administrative corruption and prevented MBO's members' activities in the universities and mosques (Abu Rumman \& Abu Haniyeh, 2013).

The 2007 elections took place under these concerns and caused intense discussions about the regime's manipulation of the election results. MBO had only six deputies in the parliament with 110 chairs and this led to claims that the government made irregularities in the elections. The dimension of the disputes caused King Abdullah II to abolish the parliament before the end of its term and to take a decision for elections in 2010 (Ryan, 2018). The reformist group in the $\mathrm{MBO}$ which was reacting to the government stance for the 2007 elections demanded reforms and boycotts for the 2010 elections. For the acceptance of their demands, their approach which provided a transition from soft opposition to a harsh and open opposition, from efficient participation to a full political partnership was supported except for a small group among moderates (Abu Rumman \& Abu Haniyeh, 2013). The irregularities in the 2007 elections and the im- 
prisonments in 2006 increased MBO's critical discourses regarding the government (Bozkurt, 2015). When the boycott of the 2010 elections is considered, it is seen that the relations between the $\mathrm{MBO}$ and the regime were quite tense before the Arab Spring started.

\section{Arab Spring and the Period Thereafter}

While the period of the Arab Spring between 2011 and 2013 was a period where positive expectations continued to meet the democratic demands, a different atmosphere began to prevail in Jordan in parallel with the developments in the region since 2013.

\subsection{1-2013 Period}

Arab Spring protest had begun in southern regions which constituted the regime's traditionalistic base as it was in the 1989 uprisings and spread to Amman and other big cities. The protests were mostly organized by East Banker Jordanians and limited with the participation of Palestine-origin Jordanians (Köprülü, 2015). The youth movements established in the southern regions played an important role in the demonstrations. The main factors motivating the "southern movement" were economic problems, unemployment and corruptions (Ryan, 2011).

Although the economic discontentment prevails among the country, it is more widespread in southern regions and East Bank because of reactions to neo-liberal policies and privatization activities implemented since the 2000s. The issues overlapping ethnic-social problems arising from the occupation of different labor markets by Palestine-origins and East Bankers give a critical dimension to the economic discontentment. East Bankers localized in the rural areas of the country work in the Army and public institutions while Palestine-origins live in central regions where urbanization, private sector and industry are centered around (Baylouny, 2008). Since the East Banker Jordanians are mostly concentrated in the public sector, they constitute the group most affected by privatization activities. They lose their jobs and social security rights because of the privatizations. In return, since Palestine-origin Jordanians work mainly in the private sector, they are less affected by economic policies.

The fact that conservative pro-regime East Bankers join the left-wing and Islamist opposition which is uncomfortable with neo-liberal policies, criticizes the regime for selling Jordanian assets for short-term gains, and even establishes a connection between these policies and Palestine-origin Queen Rania reveals a remarkable situation. While some conservative East Banker nationalists harshly criticize the regime, Palestinians from Jordanians in Arab Spring protests do not mean that they are not disturbed by the policies of the regime. But it points out that they prefer the status quo instead of instability and chaos which may arise with the overthrow of the monarchy (El Muhtaseb, 2013). When Arab Spring started to have effects in Jordan, Jordan's opposition already had a reform agen- 
da that they have been demanding for years. Strengthening the parliament, reducing some authorizations of the King, election of the prime minister by parliament, amendment of the electoral law, especially the repealing of one-person, one-vote system, rearranging constituencies in a way that allows for more democratic representation, ensuring the freedom of the press, ensuring the independence of judiciary, fight against corruption constitute the common demands of the opposition (Ryan, 2011). Since 1995, the opposition groups had established various platforms in order to ensure cooperation and coordination between themselves. Anti-Normalization Committee which brings together $\mathrm{MBO}$ and left-wing parties also has issued a call for liberalization and reform. Higher Committee for the Coordination National Opposition Parties which was established in the same year aimed to coordinate reform and democratization efforts of all opposition parties with the leadership of IAF. In 1998, National Reform Council targeted to form wider opposition coordination beyond the ones represented in Higher Committee. National Coalition for Reform which was established before the 2010 elections and involved opposition parties and civil society organizations, once again brought up the demands for changes in the electoral law (Ryan, 2011). After the beginning of Arab Spring demonstrations, in May 2011, National Front for Reform which was bringing together IAF, Jordan Women's Union and various youth movements had been established with the leadership of former Prime Minister Ahmad Ubaydat (Ryan, 2011).

Jordan's opposition, unlike other Arab countries, didn't issue a call for overthrowing the regime but demanded reform. Arab Spring protests in Jordan were generally peaceful, although some demonstrations were attacked by ultranationalist groups called "bultajiyya" and harsh intervention by security forces in some demonstrations. When the protests began, King Abdullah II aimed to reduce discontentment by means of wage concession in public sector, reintroducing fuel subventions and visiting important tribe confederations (Bank, Richter, \& Sunik, 2014). King Abdullah II changed prime ministers five times in the first 19 months of the Arab Spring, ranging from rigid conservatives to liberal reformists. These changes were interpreted as an indicator of the instability due to political protests and aroused suspicion about the abilities of the governments and the regime for finding relevant responses to public demands (Ryan, 2018). The Jordanian Administration responded to the reform demands, albeit to a limited extent, and National Dialogue Committee was established by the government in March 2011 to deal with the reform demands, and in April 2011, the Royal Constitutional Committee was established by the order of King Abdullah II to deal with the constitutional amendments. $\mathrm{MBO}$ refused to participate in National Dialogue Committee and later, this stance had been seriously criticized by Abdullah II. MBO stated that they would not accept the proposals to take part in the government until their reform demands were fulfilled.

The reform package announced in August 2011 comprises the establishment of constitutional court and independent electoral committee, restricting the au- 
thorizations of security courts and extending freedom of expression (Bank, Richter, \& Sunik, 2014). While it is envisaged that the king consults with the parliament before appointing the prime minister, the authority to appoint the prime minister and dissolve the parliament is preserved. $\mathrm{MBO}$ considered insufficient and rejected the proposals that did not meet the demand for the implementation of the constitutional monarchy as stated in the constitution. The new electoral law prepared in June 2012 revealed a mixed system that partly increased the representation of the political parties but preserved one-person, one-vote system that the opposition demanded to annul for years. Jordan MBO didn't find the changes in the electoral law sufficient, demanded that the chairs reserved for party candidates be increased to $50 \%$ and announced that it would boycott the elections if the necessary changes were not made. It was remarkable that this declaration was made right after the $\mathrm{MBO}$ candidate Mohammed Morsi won the Presidential elections in Egypt. Morsi's power influenced Jordan MBO for demanding more reform (Patel, 2015).

In the first months of Arab Spring, successive overthrow of Tunisian and Egyptian leaders, The USA and Western countries watching the leaders close to the West fall from power, supporting their demands and MBO's rise in the region led Jordan $\mathrm{MBO}$ to evaluate Hashemite regime to be weak against the developments. $\mathrm{MBO}$ members considered that uprisings were proving that the regime was weakening and the Jordan regime would be more open to their demands in order to avoid the fate of other countries where the governments were overthrow (Wagemakers, 2020). Some leaders of the Jordan MBO compared Arab Spring and the 1789 French Revolution, indicated that Arab Spring would subvert regimes in the Arab world as French Revolution had subverted European regimes and stated that if reforms were not carried out quickly, the probability of "social violence" would increase (Goldberg, 2013).

The reaction against the limited characteristic of the reforms showed itself with the low participation of $39 \%$ in the January 2013 elections, which was seen as a referendum for the reform package. Different views on the reform of USA and Saudi Arabia, two important allies of Jordan, had affected the limited characteristic of the reforms. While in the beginning, USA encouraged the King for carrying out gradual but real reforms, Saudi Arabia had given Jordan the message that it can only make limited political reforms in return for its financial support and invitation to the Gulf Cooperation Council (Barari, 2013). In order to reduce USA's pressure and obtain financial support from Gulf countries, Jordan Administration tried to "demonize" $\mathrm{MBO}$, media organs close to the state claimed that the $\mathrm{MBO}$ was not seeking reform, but seeking power, aiming to establish a religious state, and that it was an transnational agenda-following movement within the framework of its ties to the MBO Guidance Office in Egypt and Hamas, in other words presented $\mathrm{MBO}$ as a Trojan horse for external intervention (Barari, 2013).

King Abdullah II's opinions regarding MBO are quite critical. The King who 
stated in his interview dated 2013 that $\mathrm{MBO}$ which he describes as "wolves in lambskin" wanted to overthrow the government behind closed doors and it committed itself to the MBO's General Guide rather than Jordan's Constitution. The King declared that Jordan MBO leaders had decided not to participate in National Dialogue Committee after discussing this issue with Egypt MBO leaders in Cairo because they believed that there would be a revolution in Jordan and they would win. The King registered that according to the intelligence reports delivered to him, Egypt MBO leaders were encouraging their connections in Jordan to boycott the elections and destabilize the country (Goldberg, 2013). Considering these statements, it is understood that MBO's stance during Arab Spring increased the regime's mistrust of $\mathrm{MBO}$ and strengthened the judgment that they were aiming to overthrow the monarchy. On the other hand, MBO's stance has been a convenient mask for the regime for covering their failure or reluctance in preventing the socio-economic or political discontentment of the majority of the Jordanians (Milton-Edwards, 2017). Monarch responded to revolt from its traditional base by turning attention to the $\mathrm{MBO}$ and the Islamists (Köprülü, 2015).

MBO's refusal to participate in the National Dialogue Committee, boycotting the January 2013 elections, displaying a combative stance by continuing the demonstrations caused it to drift apart from its allies who were more willing to compromise and become isolated (Wagemakers, 2020). This stance of MBO's leadership not only affected their relations with other opposition groups with which they were acting together in Arab Spring but also increased the separations within MBO. Within this framework, MBO's mostly East Bank-origin moderate members who worried about the changing course of Arab Spring and its consequences and who unlike the hardliners in the MBO suggested that a more inclusive and moderate approach should be adopted, met with groups other than the Islamist movement at the Zamzam Hotel in November 2012 and established Jordan Construction Initiative, better known as Zamzam Initiative (Wagemakers, 2020). The Initiative is aimed to be a national, peaceful reform movement comprising all the colors of Jordan's political spectrum. MBO leadership harshly responded to Zamzam Initiative, expelled MBO leaders who had participated in the Initiative and claimed that the reformists were damaging Islamic movement in Jordan. The debates between Zamzam supporters and the MBO leadership took on an increasingly bitter tone. MBO's former General Comptroller Abdel Majid Thunaibat indicated that MBO within the leadership of Hamam Said chose the way of extremism by taking courage from Egypt MBO that came to power and isolated from the state (Milton-Edwards, 2015). The military coup that took place in Egypt in July 2013 increased the dissents. MBO's criticism of the Jordanian Administration for its support of military coup in Egypt, MBO's General Comptroller Hamam Said's declaration that it wasn't required that $\mathrm{MBO}$ should revise its political opinions due to developments in Egypt and Morsi's revulsion from power caused the reactions of the moderates 
(Wagemakers, 2020).

\subsection{The Period after 2013}

The military coup which happened in Egypt in July 2013 has been a critical turning point for the future of Arab Spring and the overthrow of Egypt MBO also affected other Muslim Brotherhood Organizations in the region. After the coup, the Jordanian Administration took concrete steps against MBO in the face of the closure of the Egypt MBO, the declaration of Saudi Arabia and the United Arab Emirates (UAE) $\mathrm{MBO}$ as a terrorist organization, and their pressure on the Jordanian regime to follow the same stance. Within this framework, in February 2015, MBO Deputy General Comptroller Zaki Bani Ersheid had been sentenced to 18 months imprisonment due to his expressions criticizing UAE. However, Jordan didn't identify $\mathrm{MBO}$ as a terrorist but rather it aimed to follow an indirect strategy and primarily to weaken the organization by taking advantage of dissents within the MBO. Essentially, increasing security threats due to the Syrian war, Salafis increasing popularity in the region and Jordan and separations within the organization gradually reduced the supports for MBO. While Jordanians inclined less to MBO with the fear of extremism, some of the Islamists begun to drift away from MBO because it wasn't radical enough (Schenker, 2013). The Syrian war strengthened the Salafist and Salafi-jihadist tendencies against the $\mathrm{MBO}$, and the Egyptian coup gained support for Al Qaeda's stance that rejected democratic change (Lynch, 2016).

Within this environment where the regional conditions were changing, Jordan MBO's change of status according to the new law of associations and necessity to cut off the connections with Egypt MBO became a current issue and the process leading $\mathrm{MBO}$ to be separated in two began. MBO leadership who questioned the timing and the motives of this issue which hadn't been discussed since its establishment in 1945 pointed out the role of Gulf countries (Jaber, 2017). The expelled members of $\mathrm{MBO}$ who aimed to protect Jordan $\mathrm{MBO}$ from the fate of Egypt MBO applied for license as MBA in accordance with the new law of associations. The establishment of the association was quickly approved. While the new association announced that it was the only legal and legitimate movement under the name Muslim Brothers, MBO leadership accused the regime of plotting the separation in order to weaken the organization and of intervening in the internal affairs of the organization. MBO claimed that the problem was not legal but political and that $\mathrm{MBO}$ was targeted as a result of pressures of the neighboring states (Abuqudairi, 2015). MBO leadership didn't avoid making covert threats about the anger of young Muslims in Jordan and Palestine, and hinting that banning the $\mathrm{MBO}$ would lead to thousands of young people joining jihadist groups. In April 2016, MBO's countrywide branch offices and headquarters in Amman were closed and the transfer of its assets MBA was approved. MBO resorted to the jurisdiction for the annulment of the judgment.

These developments forced MBO to take some steps. Within this context, it 
was decided to cut off the connections with Egypt $\mathrm{MBO}$, to participate in the 2016 elections, to separate MBO's and IAF's administrations and to elect by the party organs the Secretary General of the IAF who was until then elected with the recommendation of the MBO Council. In a document published in 2019 by $\mathrm{MBO}, \mathrm{MBO}$ defined itself as a Jordanian national movement which has an Islamic message and emphasized that it was representing moderation against the extremism and violence (Abu Rumman, 2020).

Although IAF attributed its decision to participate in the elections to the positive changes made in the electoral law in 2016 that abolished the one-person, one-vote system and the general tendencies in the party, it actually aimed to prevent further marginalization of $\mathrm{MBO}$ which was weaken by the pressures of the government and separations and thought that it could reduce the effects of the anti-MBO campaign in case it could manage to form an important parliamentary bloc at the end of the elections (Magid, 2016). Jordanian Administration also supported the participation of IAF as the participation of the country's largest opposition party would legitimize the elections and be a positive message to the West.

Jordan regime prefers that the opposition operates through the parliamentary channels but not in extra-parliamentary ways. Thus, it differs MBO and IAF with three reasons (Wagemakers, 2020). Within this regard; while MBO was an organization whose connections with the Egypt MBO have long been viewed with suspicion, the IAF was an utterly Jordanian political party. While MBO operated in an extra-parliamentary way that regime didn't prefer, IAF's establishment purpose was to operate in the parliament. While $\mathrm{MBO}$ was licensed as a religious charity organization in the 1940s and 1950s, IAF was a legal political party established in accordance with the Law of Political Parties dated 1992 (Wagemakers, 2020).

IAF participated in the September 2016 elections under the name of National Reform Coalition with a large list of candidates from different sectarian-religious and political groups, and won 15 out of the 130 parliamentary seats. National Congress Party which was established by Zamzam Initiative obtained three chairs (Jaber, 2017). The result obtained by Zamzam Initiative which aimed atan inclusive national movement was disappointing. On the other hand, in the November 2020 elections, National Congress Party increased its chair number to five, IAF won 10 chairs. Considering that Islamic Central Party also obtained five chairs, it is seen that IAF is facing off the competition with the Islamist parties. However, the fact that the November 2020 elections were held during the ongoing corona virus epidemic caused the participation to remain at a quite low level $(29.8 \%)$, it is stated that the participation was less than $13 \%$ in Amman (European Forum, 2020). Considering the vote potential of IAF in the large cities, it comes out that the low participation rate is against IAF.

The turning point regarding the legal status of the MBO was the Court of Cassation's decision to abolish the organization in July 2020. The Court of Cas- 
sation judged the abolishment of the organization by concluding the case that $\mathrm{MBO}$ filed against MBA and the government for the annulment of the transfer of the realties and lands in July 2020. The decision of the Court of Cassation is based on the reasoning that $\mathrm{MBO}$ didn't change its legal status in accordance with the 2014 law of associations (Ahramonline, 2020). Although MBO indicated that it had a legal license under the status of an Islamic community since 1953, official authorities stated that there was no formation which was described as a community in the Jordanian law. Based on the Court of Cassation's ruling Jordan's Ministry of Social Development issued an official announcement in December 2020 and called upon creditors and debtors to refer to the Ministry regarding any financial and legal claims from the Brotherhood (Al-Monitor, 2021).

Abu Rumman (2020) who indicated that within the framework of this development, MBO considered four options, stated that these options were maintaining its existence by following the path of Egypt MBO before the January 2011 revolution without disbanding the organization's infrastructure but by remaining in the shadows without provoking the state; focusing entirely on party activities; joining to MBA or establishing a new association with a different name. Abu Rumman who indicated that the regime was against to classify $\mathrm{MBO}$ as a terror organization and its purpose was to limit the organization with a political party by abolishing MBO's official legal status, stated that there were supporters of this view within $\mathrm{MBO}$ but this particular change required a long and complicated process.

The answer to the question of why the $\mathrm{MBO}$ didn't prepare its members for these options earlier lies in the MBO's belief that the new association will not be successful and the regime will return to them at some point (Abu Rumman, 2020). Furthermore, it is understood that MBO was thinking that the regime had hardened its stance due to pressures of Gulf countries and considered this as a temporary situation and their long and volatile relations with the regime created the thought in the members of the organization that the state would need them again. But it is observed that the regime will not allow the existence of $\mathrm{MBO}$ with its present organizational structure and staff. As a matter of fact, its stance towards the Teachers' Union revealed that the regime would follow a harsh course of action against the formations related to the MBO. Within this framework, in September 2019 one-month-long teachers strike by the Teachers' Union under the $\mathrm{MBO}$ administration which was described as the longest strike in Jordanian history was an important factor tensing the relations between the regime and MBO. The decision of the government, which ended the strike by accepting the demands of the teachers, to stop paying salary increases in the public sector in April 2020, led to the reaction of the Teachers' Union. The government, with the determination of preventing a new strike, imprisoned the board members of the union, suspended the union's activities for two years and delegated its management to a committee from the Ministry of Education. In December 2020, it is 
decided to abolish the Teachers' Union and to imprison the board members for one year (IFEX, 2021).

\section{Conclusion}

Jordan was evaluated as a country that was not affected much by the Arab Spring in the region and the developments in Jordan were given less attention in the literature. The article aims to contribute to the literature by examining the affect of the Arab Spring on the regime and MBO relations and its connection with the $\mathrm{MBO}-$ Hamas and Palestinian issue which is important for the security of the regime.

Arab Spring is a turning point in the relations between Jordan $\mathrm{MBO}$ and $\mathrm{Ha}-$ shemite Monarchy. The times when the MBO was considered as the main pillar in the stability of the regime are over, and the perception that it is an "enemy of the state" has strengthened. Although the demonstrations in Jordan were peaceful and demands for the overthrow of the regime weren't mentioned, Hashemite Monarchy watched the developments with concern. The reaction to the regime came from both the traditional opposition and the traditional supporting base. Allowing the overthrow of leaders close to the West in the early stages of the Arab Spring, especially not reacting to the fall of a leader, Egyptian President Hosni Mubarak, who was considered critically important for Israel's security in the region, worried Jordanian Monarchy which signed a peace agreement with Israel, contributed to the security of this country and which had a key role regarding the relations with USA.

Within the context of Jordanian economy dependency on international aids, in order to ensure the security of foreign incomes and continuity of Hashemite Monarchy, require Jordan to adopt a strategy that paid regard to balances both in internal and foreign policies. Within this framework, Jordanian Administration pursued a careful policy regarding reforms in response to different stances of Gulf countries and USA which were Jordan's main supporters during Arab Spring and the steps which would be taken against MBO.

It would not be wrong to state that the period between 2011 and 2013 was a wait-and-see period for both $\mathrm{MBO}$ and regime. In this period, Abdullah II's Administration adopted a relatively soft stance by means of implementing partial reforms, strengthening the dialogue with the opposition and not responding harshly to the demonstrations. On the other hand, $\mathrm{MBO}$ pursued a stricter stance in meeting the reform demands with the effects of the developments in Tunisia and Egypt. It is supposed that Jordan MBO was in expectation of forming a Muslim Brothers belt in the region within the framework of the developments within the first period of Arab Spring and aimed to weaken the legitimacy of the regime and took a combative stance by means of refusing to join in $\mathrm{Na}$ tional Dialogue Committee, continuing the protests and boycotting the elections of January 2013. However, the fact that Arab Spring didn't progress in the expected direction, especially the overthrow of the Egyptian MBO by a military 
coup, affected the Jordan $\mathrm{MBO}$ as well as all the Muslim Brotherhood in the region. The failure of democratic experience and the rising of ISIS in Iraq and Syria after the Syrian war strengthened the power of jihadists in the region while Muslim Brotherhood was weakening. The focus of Western countries on the fight against terrorism, rather than regime changes, the strengthening of authoritarian governments and the increasing pressure on Islamist movements destroyed the hopes attached to Arab Spring.

The regional equation that had been changed after the military coup in Egypt in 2013 provided appropriate condition to the regime for marginalizing MBO and initiated the process leading to the disintegration of the organization. However regime had been in a careful approach to declaring the MBO a terrorist organization and avoided describing the organization as a terrorist although it stated that it was illegal. It is possible to explain this with the role of MBO in Jordanian social and political life and the importance of its use as a foreign policy tool for regime. MBO which has wide social networks is an organization having significant supports, especially among Palestine-origin Jordanians. IAF canalizes Palestinians to the politics via legitimate tools. It would be an inaccurate approach for the regime to radicalize a large Palestinian mass by declaring the $\mathrm{MBO}$ a terrorist. On the other hand, IAF taking place in Jordanian politics as a legal party, its opposition role in the parliament enable the regime for proving that they are a "liberal" and "democratic" state to Western countries. However, for the regime, $\mathrm{MBO}$ is an organization which should be kept under control because of its pan-Islamist ideology and its relations with Hamas. Due to the importance of the Palestinian issue for the security of the regime, the Hashemite Monarchy is concerned that Hamas will be influential on Palestine-origin Jordanians through the MBO channel and become a second PLO.

Within this framework, Jordanian regime pursued a policy that extended in time and did not directly oppose the organization. It prevented reaction which might come from the base of the organization and held separated MBO and IAF. By targeting the movement, not the party, regime aimed to deprive the $\mathrm{MBO}$ of its extra-parliamentary opposition, its capacity and opportunities that enabled it to gain influence in the society and strengthen its social networks. For this reason, transferring MBO's assets to MBA is seen as an important development. The infrastructure which is necessary for ensuring the support of MBO's base-and easily controllable by state-will increase the viability of MBA. MBO has lost its legal status, its assets and part of its staff. Its offices closed, its organizational structure has been damaged. Joining into MBA is an acceptable option for neither former $\mathrm{MBO}$ staff nor MBA staff. Conducting clandestine operations is not seen as a policy that is in accordance with the traditions of the Jordan $\mathrm{MBO}$. Staying in the background and waiting for the developments reveal as a more appropriate option within the context of present conditions.

Consequently, the long-standing crisis between the Jordanian regime and $\mathrm{MBO}$ came to an end and the radical wing of the organization, which was seen 
as pro-Hamas, was eliminated. Regime indicated that it wouldn't allow MBO to exist with its present organizational structure and staff by providing the establishment of MBA. It is supposed that Arab Spring reinforced the state's understanding of strengthening the Jordanian identity and ensured the Jordanianization of the MBO, like other critical processes in Jordan's recent history.

\section{Conflicts of Interest}

The author declares no conflicts of interest regarding the publication of this paper.

\section{References}

Abu Haniyeh, H. (2016). Jordan's Strategy to Fragment the Muslim Brotherhood. Middle East Eye. https://www.middleeasteye.net/opinion/jordans-strategy-fragment-muslim-brotherhoo d

Abu Rumman, M. (2007). The Muslim Brotherhood in the 2007 Jordanian Parliamentary Elections: A Passing 'Political Setback' or Diminished Popularity? Friedrich Ebert Stiftung.

Abu Rumman, M. (2020). The Dispute over the New Rules of the Game. The State and the Muslim Brotherhood in Jordan. Friedrich Ebert Stiftung.

Abu Rumman, M., \& Abu Haniyeh, H. (2013). The "Islamist Solution" in Jordan. Islamists, the State, and the Ventures of Democracy and Society. Friedrich Ebert Stiftung.

Abuqudairi, A. (2015). Jordan's Muslim Brotherhood at Crossroads. Middle East Eye. https://www.middleeasteye.net/news/jordans-muslim-brotherhood-crossroads

Ahramonline (2020, July 16). Jordan Top Court Dissolves Country's Muslim Brotherhood.

https://english.ahram.org.eg/NewsContent/2/8/374642/Wold/Region/Jordan-top-court -dissolves-countrys-Muslim-Brother.aspx

Al-Monitor. (2021). Jordan Revisits Relationship with Muslim Brotherhood. https://www.al-monitor.com/originals/2021/01/jordan--muslim-brotherhood-dissolvecrackdown-relations.html

Bank, A., Richter, T., \& Sunik, A. (2014). Durable, Yet Different: Monarchies in the Arab Spring. Journal of Arabian Studies, 4, 163-179.

https://doi.org/10.1080/21534764.2014.971647

Barari, H. A. (2013). The Limits of Political Reform in Jordan. The Role of External Actors. Friedrich Ebert Stiftung.

Baylouny, A. M. (2008). Militarizing Welfare: Neo-Liberalism and Jordanian Policy. Middle East Journal, 62, 277-303. https://doi.org/10.3751/62.2.15

Bozkurt, A. (2015). Ürdün'de Rejim ile Müslüman Kardeşler Arasındaki İlişkilere Dair Bir Değerlendirme. Ortadoğu Analiz, 7, 64-67.

El Muhtaseb, L. (2013). Jordan's East Banker-Palestinian Schism. NOREF Norwegian Peacebuilding Resource Center.

European Forum for Democracy and Solidarity (2020). Jordan. https://www.europeanforum.net/countries/jordan

Goldberg, J. (2013). The Modern King in the Arab Spring. Atlantic. https://www.theatlantic.com/magazine/archive/2013/04/monarch-in-the-middle/309270 
IFEX (2021). Jordan Dissolves Teachers' Union and Jails Its Board Members. https://ifex.org/jordan/dissolves-teachers-union-and-jails-its-board-members/

Jaber, H. (2017). The Jordanian Muslim Brotherhood Movement: From Pillar of Monarchy to Enemy of the State. Arab Reform Initiative Research Papers.

Köprülü, N. (2015). Dönüm Noktasındaki Ürdün: Arap Baharı, Suriye Krizi ve Mülteci Hareketlerinin Ürdün'e Yansımaları. Yakındoğu Enstitüsü Yayınları.

Lucas, R. E. (2005). Institutions and the Politics of Survival in Jordan: Domestic Responses to External Challenges, 1988-2011. State University of New York Press.

Lynch, M. (2002). Jordan's Identity and Interests. In S. Telhami, \& M. Barnett (Eds.), Identity and Foreign Policy in the Middle East (pp. 26-58). Cornell University Press.

Lynch, M. (2016). In Uncharted Waters. Islamist Parties beyond Egypt's Muslim Brotherhood. Carnegie Endowment for International Peace.

Magid, A. (2016, July 13). Jordan's Muslim Brotherhood Comes in from the Cold. Middle East Eye. https://www.middleeasteye.net/news/analysis-jordans-muslim-brotherhood-comes-cold

Milton-Edwards, B. (2015). The Muslim Brotherhood: The Arab Spring and Its Future Face. Routledge. https://doi.org/10.4324/9781315659305

Milton-Edwards, B. (2017). Grappling With Islamism: Assesing Jordan's Evolving Approach. Brookings Doha Center Analysis Paper.

Patel, D. S. (2015). The More Things Change the More They Stay the Same: Jordanian Islamist Responses in Spring and Fall. Brookings Institution Rethinking Political Islam Series.

Ryan, C. R. (2011). Political Opposition and Reform Coalitions in Jordan. British Journal of Middle Eastern Studies, 38, 367-390. https://doi.org/10.1080/13530194.2011.621699

Ryan, C. R. (2015). One Society of Muslim Brothers in Jordan or Two? Middle East Research and Information Project.

Ryan, C. R. (2018). Jordan and the Arab Uprisings: Regime Survival and Politics beyond the State. Columbia University Press. https://doi.org/10.7312/ryan18626

Schenker, D. (2013). Down and Out in Amman: The Rise and Fall of the Jordanian Muslim Brotherhood. The Washington Institute for Near East Policy.

Turan, K. (2011). Ürdün'de Muhalif Hareketler. Gazi Akademik Bakış, 4, 95-112.

Wagemakers, J. (2020). Between Exculisivism and Inclusivism: The Jordanian Muslim Brotherhood's Divided Responses to the "Arab Spring". Middle East Law and Governance, 12 , 35-60. 